http://jmscr.igmpublication.org/home/

ISSN (e)-2347-176x ISSN (p) 2455-0450

crossref DOI: https://dx.doi.org/10.18535/jmscr/v9i11.25

Journal Of Medical Science And Clinical Research

\title{
Comparative in-vitro anthelmintic activity of various parts of Ficus Carica linn
}

Authors

\author{
Sudheshna Loka ${ }^{1}$, Rajyalaxmi Masula ${ }^{2}$, Prakashamani Guntuku ${ }^{3}$
}

${ }^{1,2,3}$ Assistant Professor, Gland Institute of Pharmaceutical Sciences, Shangrila Farms, Kothapet, Medakdist

\begin{abstract}
Many commonly available plants like Leonatisleptiifolia, various species of Ficus like Ficus benghalensis, Ficus religiosa etc showed potent anthelmintic activity. The present study was aimed to compare the potencies of various parts of Ficus carica against earth worms as they anatomically resemble the round worms which cause helmenthiasis. Methanolic extract of leaves, stems and fruits of Ficus carica were compared for their in-vitro anthelmintic activity in order to determine the potencies of them. Results revealed that exposure of worms to leaf extract of F.carica takes 2-3 hr to cause paralysis and death of worms with various concentrations of $(20,30,40 \mathrm{mcg} / \mathrm{ml})$. The stem extract of F.carica shows almost equal effect with 3 hrs of exposure. While the methanolic fruit extract of F.carica is effective at more than 3 hrs of exposure. The results were compared with mebendazole as a positive control and normal saline as a negative control. Mebendazole shows $100 \%$ effective on exposure, while worms exposed to normal saline were still alive even after 3 hrs of exposure.

Keywords: Ficus benghalensis, helmenthiasis, Mebendazole, earth worms.
\end{abstract}

\section{Introduction}

Helminthiasis, also known as worm infection, is any macro parasitic disease of humans and other animals in which a part of the body is infected with parasitic worms, known as helminthes. ${ }^{1}$ Medicinal plants like Ficus species are the potent source of many pharmacological activities. ${ }^{2,}{ }^{10}$ The present study was aimed to investigate the potencies of various parts of Ficus carica against Pheritima postuma (Indian earth worm). ${ }^{11}$

\section{Materials and Methods}

\section{Plant Collection and Extraction}

$>$ Ficus carica was collected from soil of Sangareddy, Medak district, Telangana and authenticated by Prof. P.Jayaraman, Ph.D from plant anatomy research center in Tamil nadu.
$>$ Plant was cleaned; leaves, stems and fruits are separated and are shade dried.

$>$ Dried leaves and stems were grounded to attain a coarse powder.

$>$ These powders were kept for soxhlation in $250 \mathrm{ml}$ of methanol for 1 day individually and thus attained the methanolic extract of leaves and stems and were kept for evaporation.

$>$ Dried fruits were grounded to attain small particles.

$>$ These particles were macerated in $250 \mathrm{ml}$ of methanol for 3 days and the attained methanolic extract of fruits was kept for evaporation.

$>$ The obtained extracts were used to test the activity. 


\section{Method of Extraction}

The leaves, stems and fruits of Ficus carica were collected. These parts are washed with water for removal of dirt and dried in the shade at room temperature for a period of seven days. Dried parts were coarsely powdered.

\section{- Extraction of the leaves: ${ }^{4}$}

$50 \mathrm{gm}$ of leaf powder was weighed and subjected for soxhelet extraction with $250 \mathrm{ml}$ of methanaol.

\section{- Extraction of the stems: ${ }^{3}$}

$50 \mathrm{gm}$ of stem powder was weighed and subjected for soxhelet extraction with $250 \mathrm{ml}$ of methanaol.

\section{- Extraction of the fruit: ${ }^{5}$}

Fruiit extraction was prepared by using maceration process.

\section{Phytochemical screening: ${ }^{8}$}

Phytochemical studies on F. carica revealed the presence of numerous bioactive compounds such as phenolic compounds, phytosterols, organic acids, anthocyanin few other classes of secondary metabolites from different parts of F. carica. Most species of F. carica contain phenolic compounds, organic acids, and volatile compounds. $40 \mathrm{mcg} / \mathrm{ml}$. All the times are noted and the activity is calculated. ${ }^{6,7,9}$

\section{Anthelminthic activity:}

Earthworms (Pheretima posthuma) were collected. They are washed with saline solution in order to remove all the earthy matter. Properly washed and sterilized petri plates are taken. Standard vehicle is prepared by mixing 5\% Dimethyl sulfoxide in normal saline solution and placed in the petri plate. All the leaf, stem and fruit extracts are mixed with the standard vehicle and placed in three different petri plates respectively. In each petri plate 3-5 earth worms are placed and the lids of petri plates are closed partially by leaving an air space. Time of earthworms placed is noted and the activity is to be monitored. Then the time of death of earthworms are to be noted. This procedure is repeated for different concentrations of extracts i.e., $20 \mathrm{mcg} / \mathrm{ml}$, $30 \mathrm{mcg} / \mathrm{ml}$ and $40 \mathrm{mcg} / \mathrm{ml}$. All the times were noted and the activity is calculated. ,, $9^{-9}$

\section{Results and Discussion}

From the observations of table1, it shows that leaf extract of ficus carica killed all worms in $2 \mathrm{hrs}$ having $100 \%$ efficacy. Stem and fruit extract showed the efficacy in about 2-3hrs based on the concentration of drug. Three different concentrations of drug are been considered and compared for their efficacy.

The results were compared with mebendazole as positive control and normal saline as negative control where mebendazole shows $100 \%$ efficacy in about 1-2hrs of exposure whereas normal saline doesn't show any effect until 3 hrs hence worms remain still alive.

Table 1: Effects of methanolic extract on the motility of worm

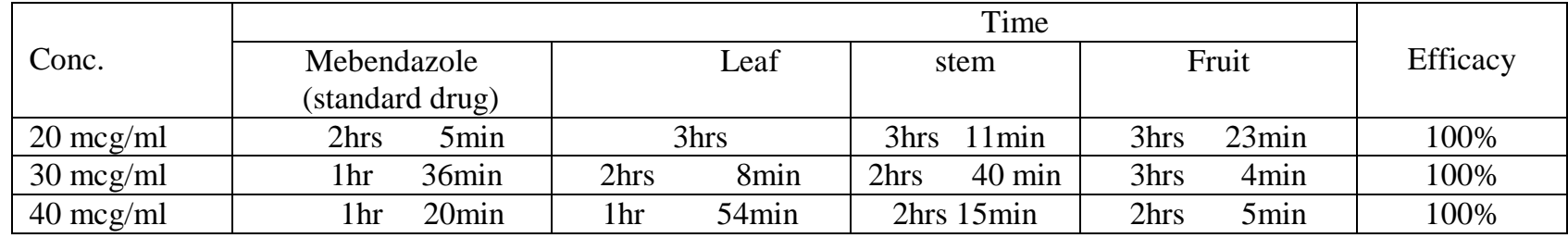

From the above table, it is proved that methanolic leaf extract shows more potent activity than methanolic stem and fruit extracts. It also shows that as the concentration of drug increases the time required for the paralysis and death of worm was decreased.

Table 2: Leaf extracts values for anthelmintic activity

\begin{tabular}{|l|c|}
\hline Concentration & leaf extract(time of death) \\
\hline $20 \mathrm{mcg} / \mathrm{ml}$ & $3 \mathrm{hrs}$ \\
\hline $30 \mathrm{mcg} / \mathrm{ml}$ & $2 \mathrm{hrs}$ \\
\hline $40 \mathrm{mcg} / \mathrm{ml}$ & $1 \mathrm{hr} 54 \mathrm{~min}$ \\
\hline
\end{tabular}




\section{JMSCR Vol||09||Issue||11||Page 133-136||November}

Table 3: Stem extracts values for anthelmintic activity

\begin{tabular}{|l|c|}
\hline Concentration & stem extract(time of death) \\
\hline $20 \mathrm{mcg} / \mathrm{ml}$ & $3 \mathrm{hrs} 11 \mathrm{~min}$ \\
\hline $30 \mathrm{mcg} / \mathrm{ml}$ & $2 \mathrm{hrs} 40 \mathrm{~min}$ \\
\hline $40 \mathrm{mcg} / \mathrm{ml}$ & $2 \mathrm{hr} 15 \mathrm{~min}$ \\
\hline
\end{tabular}

Table 4: Fruit extract values for anthelmintic activity

\begin{tabular}{|l|c|}
\hline Concentration & Fruit extract(time of death) \\
\hline $20 \mathrm{mcg} / \mathrm{ml}$ & $3 \mathrm{hrs} 23 \mathrm{~min}$ \\
\hline $30 \mathrm{mcg} / \mathrm{ml}$ & $3 \mathrm{hrs} 4 \mathrm{~min}$ \\
\hline $40 \mathrm{mcg} / \mathrm{ml}$ & $2 \mathrm{hr} 52 \mathrm{~min}$ \\
\hline
\end{tabular}

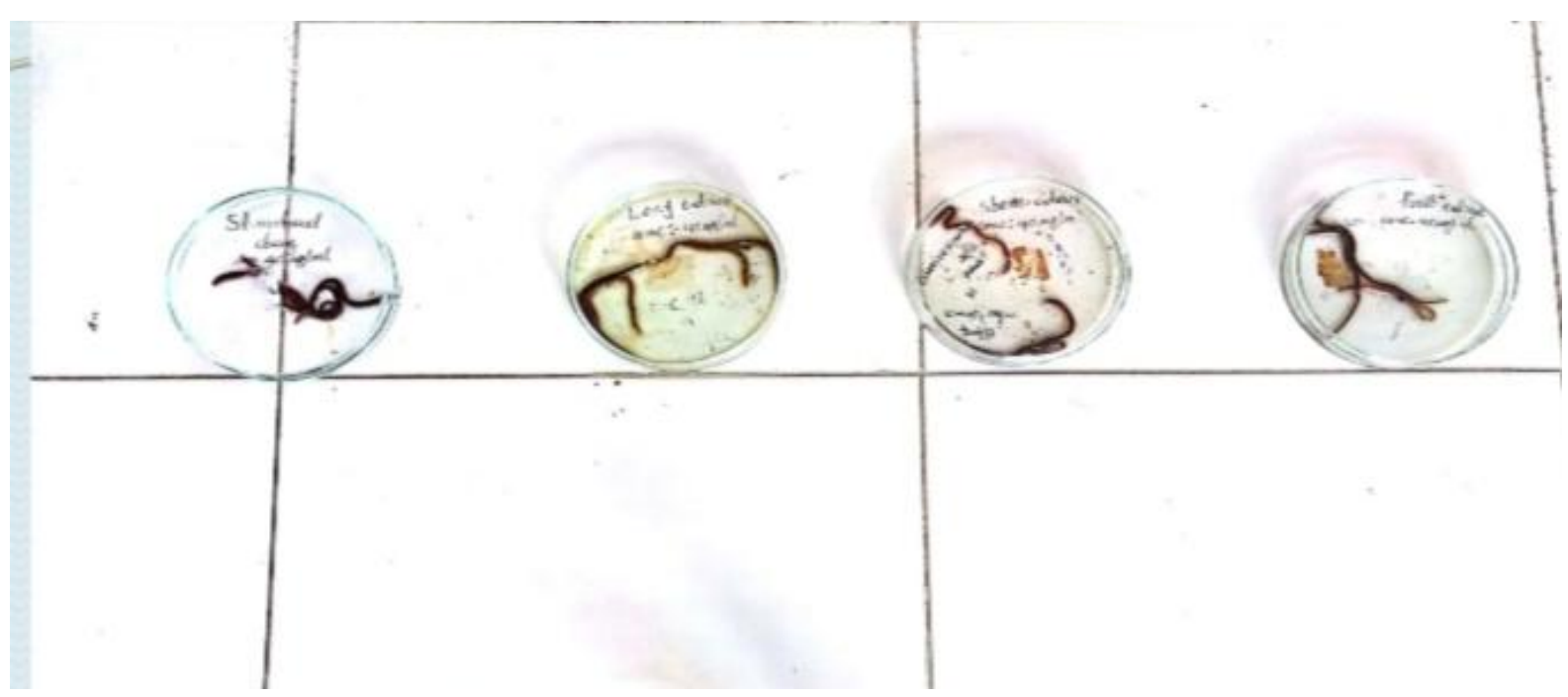

Figure 1: Anthelmenthic activity of methanolic extract of various plant parts of Ficus carica

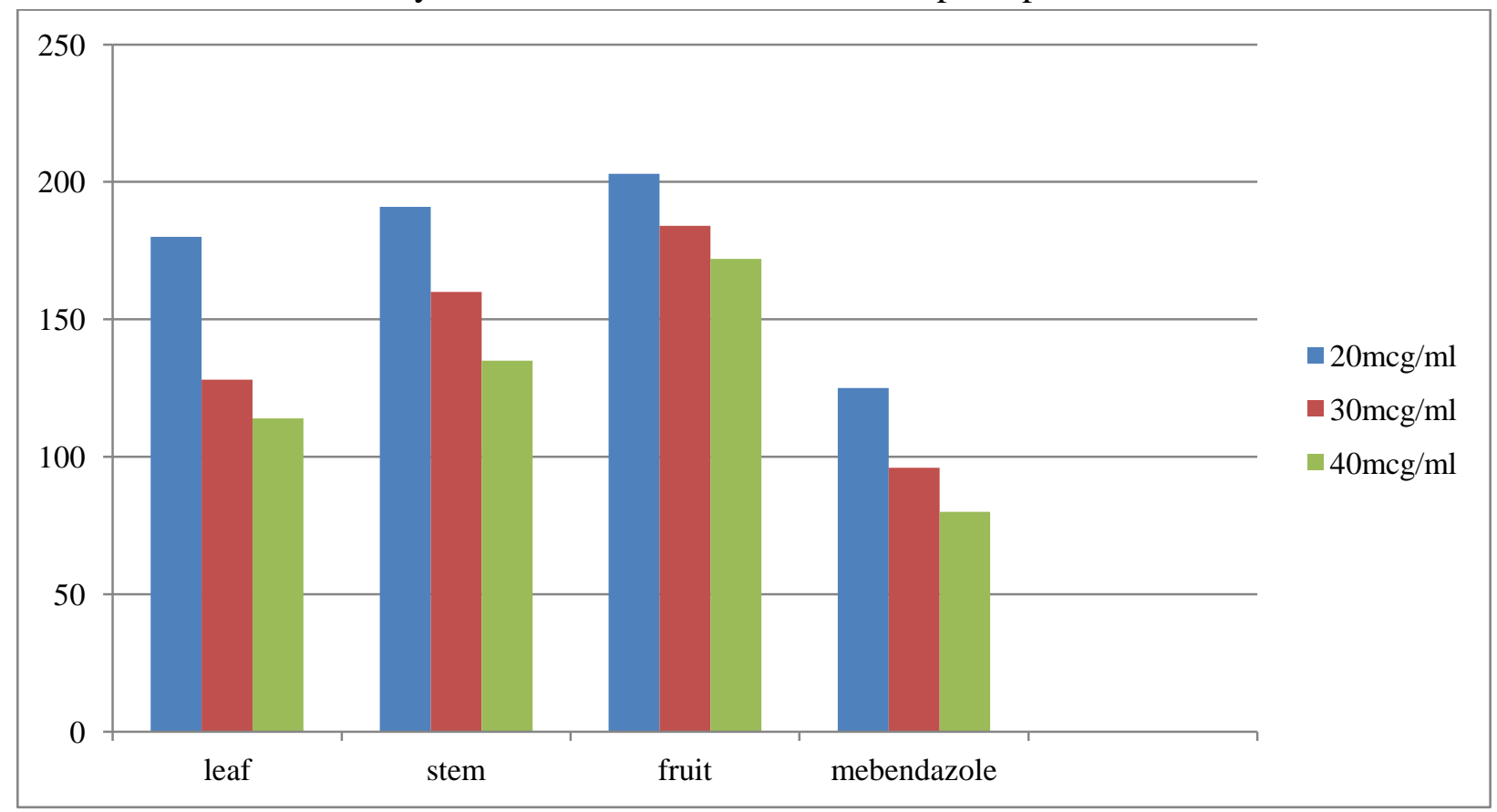

Graphical representation of antihelminthic activity of various parts of ficus carica

The above chart illustrates the death time of worms on $y$-axis in minutes and concentration of different extracts on $\mathrm{x}$-axis. Leaf extract shows quick response and the worms became immotile, paralyzed and finally dead in a shorter time compared to stem and fruit extracts $(20 \mathrm{mcg}-3 \mathrm{hrs}$, 


\section{JMSCR Vol||09||Issue||11||Page 133-136||November}

30mcg-2hrs $28 \mathrm{~min}, 40 \mathrm{mcg}-1 \mathrm{hr} 54 \mathrm{~min})$. The stem showed the activity a little later than the leaf extract (20mcg-3hrs $11 \mathrm{~min}, 30 \mathrm{mcg}-2 \mathrm{hrs} 40 \mathrm{~min}$, $40 \mathrm{mcg}-2 \mathrm{hr} 15 \mathrm{~min})$. Fruit produced anthelmenthic activity latest than leaf and stem is about (20mcg-3hrs 23min, $30 \mathrm{mcg}-3 \mathrm{hrs} 4$ minand $40 \mathrm{mcg}$ - $2 \mathrm{hrs} 52 \mathrm{~min}$ ). Bottom-line of the activity is that all the three parts of the plant Ficus carica possess potent anthelmenthic activity.

\section{References}

1. Ryabokone.v., onishchenko, the detailed description on heiminthiasis disease, isnc, 2013

2. Gordon MC, David JN. Natural product drug discovery in the next Millennium, Pharmaceutical Biology, 2001, 39: 8-17.

3. Antibacterial activity of Ficuscarica L. extract against six bacterial strains Hiba Hazim Hamid Al-Yousuf*

4. Methanolic Extract of Ficuscarica Linn. leaves exerts Antiangiogenesis Effects Based on the Rat Air Pouch Model of Inflammation Tahereh Eteraf-Oskouei, Saeideh Allahyari, Arezu AkbarzadehAtashkhosrow, Abbas Delazar, Mahdiyeh Pashaii, Siew Hua Gan, and Moslem Najafi

5. Anticancer Activity of Methanol Extract of Ficuscarica Leaves and Fruits Against Proliferation, Apoptosis, and Necrosis in Huh7it Cellsby Risa Purnamasari, Dwi Winarni, Adita Ayu Permanasari, Eva Agustina, Suhailah Hayaza, and Win Darmanto

6. C.h. chandrashekar, k.p. latha article, anthelmintic activity, department of chemisty,2008

7. snehal $\mathrm{r}$ adsul, patilh.s, method for anthelmintic activity on earthworms, journal of Pharmaceutical research,2013

8. Ficuscarica L. (Moraceae): Phytochemistry, Traditional Uses and Biological Activities Shukranul Mawa, Khairana Husain, and Ibrahim Jantan.
9. Evaluation of anthelmenthic activity of Carica papaya latex using pheritima posthuma lakshmikantha kanthal, prasenjitmondal, somnath de, sidhabathunianeela, satyavathi, Samuel george.

10. Devi rajeshwari, plants showing anthelmenthic activity, research journal of phytochemistry, 2014.

11. Determination of Anthelmintic Activity of the Leaf and Bark Extract of Tamarindus Indica Linn S. S. Das,1 Monalisha Dey, and A. K. Ghosh2,* 